\title{
China-ASEAN SME Cooperation Under the Belt and Road Initiative Obstacles and Path Choices to Deepen Development
}

\author{
Shaogang Liao, Zhikang Luo \\ School of Finance, Taxation and Public Administration, Jiangxi University of Finance and Economics, Nanchang, China
}

Email address:

liaoshaogang@163.com (Shaogang Liao)

\section{To cite this article:}

Shaogang Liao, Zhikang Luo. China-ASEAN SME Cooperation Under the Belt and Road Initiative Obstacles and Path Choices to Deepen Development. International Journal of Business and Economics Research. Vol. 9, No. 3, 2020, pp. 117-124. doi: 10.11648/j.ijber.20200903.14

Received: March 23, 2020; Accepted: April 20, 2020; Published: May 14, 2020

\begin{abstract}
As a national strategy initiated by China and promoted by high-level officials, the "Belt and Road Initiative" has received great attention from the international community. As the fulcrum of the Silk Road Economic Belt and the main hub of the major power strategy, cooperation between China and ASEAN is crucial. The establishment of the ASEAN Economic Community has brought a lot of business opportunities to the ASEAN countries, The ASEAN economy is continuing to grow. The "Belt and Road" initiative proposed by China has promoted economic cooperation and development between China and ASEAN, The China-ASEAN Free Trade Area has been further upgraded, opening markets to each other provides more favorable conditions for cooperation between the two sides. As the main carrier of employment, small and medium-sized enterprises play an important role in activating the economy, absorbing employment, promoting innovation, increasing taxes, facilitating the people and benefiting the people. Strengthening cooperation between SMEs in China and ASEAN is conducive to promoting industrial restructuring and industrial upgrading on both sides, promoting sustained economic growth in China and ASEAN countries, further expanding the common open market between China and ASEAN, promoting regional economic integration, and promoting the growth of the world economy. However, at present, China and ASEAN countries still face many constraints in the cooperation of small and medium-sized enterprises. The overall competitiveness of SMEs is not strong, the ability to develop international markets is weak, financing difficulties, lack of professional personnel and other issues need to be resolved. This article analyzes the opportunities and dilemmas faced by China-ASEAN SMEs at this stage, and proposes countermeasures to promote China-ASEAN SMEs to deepen cooperation.
\end{abstract}

Keywords: The "Belt and Road", China-ASEAN, SME Cooperation, Competitiveness, Complementarity

\section{Introduction}

With the in-depth advancement of the "Belt and Road" initiative, China-ASEAN bilateral relations have developed rapidly and made significant progress. In addition to strategic cooperation at the macro level, China-ASEAN cooperation is more importantly the close cooperation between bilateral companies in the trade process. Due to the flexibility and extensiveness of trade cooperation forms, SMEs can play a solid and strengthening role in the existing trade cooperation areas between China and ASEAN countries. And in looking for new points of trade growth and development, SMEs have greater advantages. As the main carrier of employment, SMEs play an important role in promoting social stability. At the same time, SMEs also play an irreplaceable role in promoting technological innovation and invigorating the national economy. China and ASEAN countries are increasingly aware of the important role played by SMEs in promoting international economic and trade cooperation, promoting complementary advantages, enhancing bilateral trade, promoting economic restructuring, reducing poverty and narrowing the gap between rich and poor.

\section{Literature Review}

Zhu Meilin and Wang Liqin (2017) on the theme of Chinese leaders in building China-ASEAN relations over the past two decades are "cooperation" and "development". It is predicted 
that China will continue to work to promote political mutual trust and security with ASEAN. Cooperation [1]. Quan Yi and Gao Junxing (2018) conducted a survey of 14 overseas industrial cooperation parks established by China in ASEAN countries and found that the current overseas industrial cooperation parks established by China in ASEAN not only lack domestic policy support, lack of business strategies, and internationalization Insufficient talent support, financing difficulties, single profit model, etc., and facing investment risks caused by host country political turmoil, irregular laws, changeable policies, and cultural and traditional differences [2]. Based on the perspective of China-ASEAN Free Trade Area, Zhao Diqiong (2012) proposed that SMEs faced a large funding gap, a single financing channel, and a difficult mortgage guarantee in their development [3]. Shen Tao and Yao Yunfeng (2019) analysis based on economic, political and cultural perspectives: cultural distance, financial cooperation and political relations have a direct impact on production capacity cooperation, and the degree of impact weakens in turn [4]. Nie Honglong (2019) analyzed the current status of China-ASEAN bilateral trade from the perspective of trade scale and trade structure, and analyzed the competitiveness and complementarity of bilateral trade from the perspective of countries and products [5].

Jin Dan (2019), from the perspective of political diplomacy, believes that bilateral and multilateral relations between China and ASEAN countries still face a deficit of mutual trust in politics and security, imbalance in economic and trade development, provocations by foreign countries, sovereignty disputes in the South China Sea, extreme nationalist emotional interference and There are many difficulties and challenges such as conflicts caused by multiple cooperation mechanisms. Improving the status of policy communication between the two sides needs to be easy, then difficult, step by step, classified and implemented, and key breakthroughs [6]. You Hongbing and Xu Mengyun (2019) proposed that China-ASEAN sides should adhere to the "joint consultation, co-construction, and sharing" to promote mutual trust and implement the financial supervision policy of "seeking common ground while reserving differences" to promote bilateral financial cooperation [7]. Cui Xiaojing and Xiong Xin (2019) Combining the status quo of deepening tax collection and management cooperation between China and the countries along the route, it is suggested that China should actively participate in the construction of a regional tax collection and management cooperation platform to enhance the tax collection and management capabilities of the countries along the route [8]. Fu Yuanjia (2019) believes that it is necessary to further accurately define the development orientation and clarify the development ideas, build a new era of comprehensive opening up, fully play the role of the gateway and fulcrum of the channel, vigorously develop international markets along the route, actively build a transnational industrial belt, and accelerate the development of new western land and sea channels Construction of container trunk ports, integration of open platforms and projects, innovation of open platform development models, deepening of maritime interoperability and marine cultural exchanges [9].

\section{Opportunities Brought by the "Belt and Road" Initiative to the Development of China-ASEAN SMEs}

In recent years, China's economic and trade cooperation with the 10 ASEAN countries has become closer. As can be seen from the figure 1, the ranking of China's major trading partners has changed, and ASEAN has become China's second largest trading partner. In 2019, China's largest trading partner is still the European Union, with imports and exports to the EU of 4.86 trillion yuan, an increase of $8 \%$; imports and exports to ASEAN 4.43 trillion yuan, an increase of $14.1 \%$; imports and exports to the United States, 3.73 trillion yuan, a decline $10.7 \%$; imports and exports to Japan were 2.17 trillion yuan, an increase of $0.4 \%$. In addition, China 's imports and exports to countries along the "Belt and Road" were 9.27 trillion yuan, an increase of $10.8 \%$, which was 7.4 percentage points higher than the overall growth rate. In 2019, ASEAN overtook the United States for the first time to become China's second largest trading partner. For ASEAN, China has been ASEAN's largest trading partner since 2009.

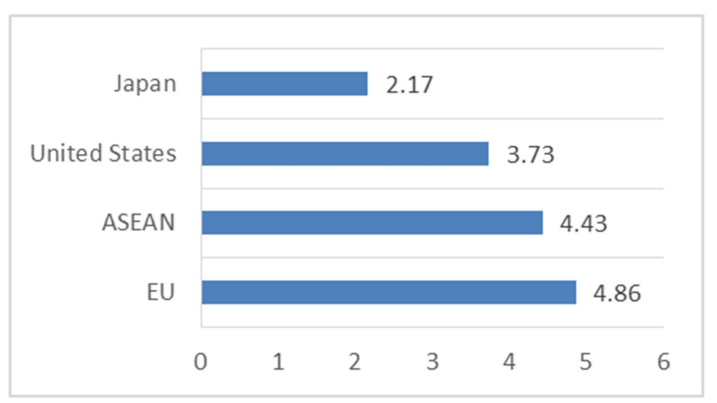

Figure 1. Total imports and exports between China and major trading partners in 2019 (Unit: trillion).

As can be seen from the Table 1, among the ten ASEAN countries, Indonesia has the highest total GDP. As of the end of 2018, Indonesia's GDP was more than 1 trillion US dollars, about 1042.17 billion US dollars. Indonesia is the most populous country in ASEAN, with a population of 267.67 million and a GDP per capita of about 3890 USD. Myanmar and Cambodia have the lowest GDP per capita, at US \$1,330 and US \$ 1,510 respectively. Among them, Myanmar's total GDP in 2018 was approximately 71.21 billion US dollars and its population was approximately 53.71 million; Cambodia's 2018 GDP was approximately 24.57 billion US dollars and its population was approximately 16.25 million. Singapore's GDP growth rate again exceeded $3 \%$ in 2018 , with a GDP of approximately US $\$ 364.16$ billion and a population of approximately 5.64 million, while its per capita GDP exceeded US \$ 64,000, far exceeding other ASEAN countries. Brunei's GDP per capita is also very bright, exceeding 31,000 US dollars, second only to Singapore among ASEAN countries. However, the total population of Brunei is too small, only 430,000, and the total GDP is only 13.57 billion US dollars, which has a small influence in ASEAN. In 2018, Thailand's actual economic growth rate was $4.1 \%$, with a GDP 
of approximately US \$ 504.99 billion, a population of 69.43 million, and a per capita GDP of approximately US \$ 7270; Malaysia, in 2018, the actual domestic currency growth rate of GDP was $4.7 \%$, and the total GDP was approximately It was 354.35 billion US dollars, with a population of about 31.53 million people, and the per capita GDP exceeded 11,000 US dollars. In 2018, the Philippine economy grew by $6.2 \%$ in real terms, with a total GDP of US \$ 330.91 billion, a population of approximately 106.65 million, and a per capita GDP of approximately US \$3100. Vietnam 's actual economic growth in 2018 was $7.08 \%$, with a GDP of approximately 224.95 billion USD, population is about 95.54 million, and per capita GDP is about USD 2350.

Table 1. Comparison of GDP, population, and per capita GDP of the ten ASEAN countries in 2018.

\begin{tabular}{llll}
\hline country & GDP (billion US dollars) & Population (million) & GDP per capita (thousands of US dollars) \\
\hline Indonesia & 10421.7 & 267.67 & 3.89 \\
Thailand & 5049.9 & 69.43 & 7.27 \\
Singapore & 3641.6 & 5.64 & 64.57 \\
Malaysia & 3543.5 & 31.53 & 11.24 \\
Philippines & 3309.1 & 106.65 & 3.10 \\
Vietnam & 2249.5 & 95.54 & 2.35 \\
Myanmar & 712.1 & 53.71 & 1.33 \\
Cambodia & 245.7 & 16.25 & 1.51 \\
Laos & 181.3 & 7.06 & 2.57 \\
Brunei & 135.7 & 0.43 & 31.56 \\
\hline
\end{tabular}

Table 2. GDP growth rate (\%) forecast of some ASEAN countries.

\begin{tabular}{|c|c|c|c|c|c|c|}
\hline country & 2016 & 2017 & 2018e & 2019f & $2020 f$ & $2021 f$ \\
\hline Cambodia & 7.0 & 7.0 & 7.5 & 7.0 & 6.9 & 6.8 \\
\hline Indonesia & 5.0 & 5.1 & 5.2 & 5.2 & 5.3 & 5.3 \\
\hline Laos & 7.0 & 6.9 & 6.5 & 6.6 & 6.7 & 6.6 \\
\hline Malaysia & 4.2 & 5.9 & 4.7 & 4.6 & 4.6 & 4.6 \\
\hline Myanmar & 5.9 & 6.8 & 6.2 & 6.5 & 6.6 & 6.8 \\
\hline Philippines & 6.9 & 6.7 & 6.2 & 6.4 & 6.5 & 6.5 \\
\hline Thailand & 3.4 & 4.0 & 4.1 & 3.5 & 3.6 & 3.7 \\
\hline
\end{tabular}

Note: $\mathrm{e}=$ estimate; $\mathrm{f}=$ forecast. The World Bank's forecasts are constantly updated with new information and a changing (global) environment. As a result, the projections presented here may differ from those contained in other World Bank documents, even if the basic assessment of country prospects does not differ significantly at any given moment.

Information from the International Monetary Fund (IMF) in the Global Economic Outlook report (Table 2) shows that the actual economic growth rate of the ASEAN region in 2018 will exceed 5\%. Among them, Cambodia has the highest real GDP growth, and its actual GDP growth rate in 2018 was about $7.5 \%$. This was followed by Vietnam with $7.1 \%$, Laos with $6.5 \%$, Philippines and Myanmar with $6.2 \%$, Indonesia with 5.2\%, Malaysia with $4.7 \%$ and Thailand with $4.6 \%$. It is expected that the average economic growth of ASEAN in 2019 will be more than $5 \%$, and the economic growth of five of the ten ASEAN countries (Vietnam, Cambodia, Laos, the Philippines, and Myanmar) will be $6.5 \%-7 \%$. There is a large demand for infrastructure construction in ASEAN, a large demand for machinery and equipment for industrial upgrading, and a smart city construction plan being implemented by ASEAN. These will bring more business opportunities to the cooperation between China and ASEAN.

Table 3. 2018-2019, China's imports and exports to the six ASEAN countries (unit: billion US dollars).

\begin{tabular}{|c|c|c|c|c|c|c|c|c|}
\hline \multirow[b]{2}{*}{ country } & \multicolumn{2}{|l|}{ Exports } & \multicolumn{2}{|l|}{ Imports } & \multicolumn{2}{|c|}{ Imports and exports } & \multicolumn{2}{|c|}{ Percentage of China-ASEAN total trade volume (\%) } \\
\hline & 2018 & 2019 & 2018 & 2019 & 2018 & 2019 & 2018 & 2019 \\
\hline Indonesia & 432.095 & 409.937 & 341.617 & 315.643 & 773.712 & 725.580 & 13.16 & 12.55 \\
\hline Malaysia & 454.033 & 467.610 & 632.221 & 647.464 & 1086.254 & 1115.074 & 18.48 & 19.29 \\
\hline Philippines & 350.615 & 369.846 & 206.071 & 185.543 & 556.686 & 555.389 & 9.47 & 9.61 \\
\hline Singapore & 491.653 & 485.217 & 337.151 & 317.810 & 828.804 & 803.027 & 14.1 & 13.89 \\
\hline Thailand & 428.931 & 409.868 & 446.319 & 419.235 & 875.250 & 829.103 & 14.89 & 14.34 \\
\hline Vietnam & 838.997 & 884.037 & 639.587 & 571.397 & 1478.584 & 1455.434 & 25.15 & 25.18 \\
\hline
\end{tabular}

As can be seen from the Table 3, from January to November 2019, China's bilateral trade with Vietnam, Malaysia, and Thailand was 1,455.4434 billion US dollars, 111.05474 billion U.S. dollars, and 82.103 billion U.S. dollars, ranking among the top three in total trade with China and ASEAN, respectively They accounted for $25.18 \%, 19.29 \%$, and $14.34 \%$ of the total trade volume.

In addition, China-ASEAN economic and trade complementarities in terms of production capacity, agricultural products, and infrastructure are strong. The enterprises of both sides also have the advantages of a geographically-linked cooperation location, which facilitates 
communication. The cost-effectiveness of Chinese products is obvious, which is in line with the consumer demand and consumption level of ASEAN countries. Some ASEAN countries have abundant natural resources, low labor costs, and Investment incentives. These factors are very conducive to the growth and development of SMEs. Therefore, under the Belt and Road Initiative, China-ASEAN SMEs face rare development opportunities.

\section{Constraints on China-ASEAN SME Cooperation and Development}

\subsection{Low Political Mutual Trust and Imbalanced Bilateral Economic and Trade Development}

Due to obstacles caused by cultural differences and ideological conflicts between China and ASEAN countries, and territorial disputes in the South China Sea, although the "Belt and Road" initiative has the support of ASEAN members, some ASEAN members still have doubts about the "Belt and Road" initiative Some members are still cautious about China-ASEAN long-term economic cooperation, and Some countries worry that cooperation will weaken the cohesion and central position of ASEAN and make it difficult to cope with China's regional and even global development. In addition, individual countries outside China-ASEAN are reluctant to see China's development and economic and trade cooperation with ASEAN due to political purposes and economic interests. They have established obstacles through various channels, individual western countries often write about the differences in ideology between China and ASEAN and advocate the so-called "China threat theory" in an attempt to undermine the cooperative relationship between China and ASEAN.

The economic development of the ten ASEAN countries is uneven, the legal basis for investment and market access are different, the business environment and policy mechanisms are also quite different, and the legal systems of many ASEAN countries are not sound, imperfect, and unstable. ASEAN countries have inconsistent policies in promoting cooperation among SMEs. Facing the implementation of multiple economic projects under the "Belt and Road" initiative, and most of these projects are docked with individual ASEAN members, instead of docking with all members, some ASEAN countries are worried that due to China 's strong economic strength, China will dominate the bilateral cooperation projects. Some countries believe that this is not conducive to taking ASEAN as the core and may weaken the cohesion of ASEAN. Such doubts have created certain challenges for China and ASEAN to further deepen their cooperation with SMEs. To some extent, it limits the space for ASEAN countries to coordinate economic policies with each other, which leads to a weak foundation for expanding economic cooperation among countries and affects the deepening of cooperation between China and ASEAN SMEs. Not only that, China-ASEAN SME cooperation also faces the rise of current global trade and investment protectionism and the impact of anti-globalization.

\subsection{Information Channels Are Not Smooth and Business Channels Are too Narrow}

Small and medium-sized enterprises are limited by their own size, lack of international cooperation experience, obstacles such as inaccessible information in the international market, incomprehensible foreign cultures and customs, and inconvenient communication and communication. The use of Malay, Thai in Thai, and language barriers will hinder the development of SMEs and even directly affect investors' market judgment and investment decisions. In addition, the political, economic, and cultural developments of ASEAN countries are different, and the strategic cooperation attitudes of different countries and China are different. For example, countries such as Singapore actively cooperate and achieve mutual benefit, while Vietnam and other countries have somewhat ambiguous attitudes, which will affect Investment judgments and decisions for SMEs. However, the international operation of small and medium-sized enterprises requires enterprises to be sensitive to changes in the international market and quickly make corresponding strategic plan adjustments. The business channels of small and medium-sized enterprises are too narrow, and the ASEAN business information that can be obtained is not abundant, which restricts investment or trade benefits. Some Chinese SMEs lack information about ASEAN countries' political positions, market trends, industry planning, and development policies, and information channels are not smooth. At the same time, the investment channels of SMEs in ASEAN countries are also very limited. At the same time, investment channels for SMEs in ASEAN countries are also very limited. The lack of business communication partners and investment information consulting and exchange platforms has resulted in asymmetric trade information between the two parties, failed to obtain the required market information in a timely manner, and failed to understand the market trends of countries in a timely manner, leading to the depression of the bilateral markets, it is difficult for small and medium enterprises to cooperate.

At the same time, the market economy development mechanisms of some ASEAN countries are inadequate in science and rationality, the procedures for the approval and supervision of international cooperation projects are not complete, and experience in dealing with problems is insufficient. This also makes Chinese SMEs face a very complicated investment environment in ASEAN. Some Chinese SMEs face opaque and unstable investment policies in ASEAN countries, and even face corruption and slow administrative efficiency, which will affect the innovation and sustainable development of China-ASEAN SME cooperation.

\subsection{Financing Difficulties for SMEs, Imperfect Financing Laws and Regulations}

SMEs have become an important force in China's foreign trade. For small and medium-sized enterprises to enter the 
market of ASEAN countries, active subjective initiative alone is not enough. The development of foreign trade enterprises requires a lot of financial support. The shortage of funds has always been a bottleneck restricting the further development of SMEs, especially in foreign trade financing. On the one hand, the credit status of SMEs is poor, and the guarantee conditions are difficult to meet the requirements of banks, the level of SMEs' own credit directly affects whether they can obtain trade financing from banks. On the other hand, there are insufficient institutions dedicated to financing small and medium-sized enterprises, due to technical and scale limitations, regional local financial institutions are unable to provide comprehensive international trade financing services.

At the same time, China's trade financing regulations are inadequate at this stage, and financial legislation has lagged behind the development of financial business. Relevant laws on international trade financing have not yet clearly defined the rights and responsibilities of activities involved in business, including mortgages, trusts, and other acts. At this stage, the laws and regulations on trade financing still do not conform to international practices. The imperfect trade financing process and the lack of financial legislation make banks and enterprises face greater risks in international trade financing business. Foreign SMEs also face the practical problem of lack of funds, which hinders the development of bilateral trade cooperation between China and ASEAN SMEs.

\subsection{Low Technical Content of Products, Not Strong International Competitiveness}

China and ASEAN SMEs have extensive cooperation prospects, but there are also obvious limitations. At present, China's small and medium-sized enterprises are subject to restrictions in terms of funds, talents, and technology. The form of export trading products is too simple, resulting in a small amount of foreign trade transactions. In addition, due to higher tariffs, small and medium-sized enterprises have high production costs and small profits. Small and medium-sized enterprises have a weak foundation and their competitiveness in the international market is not strong. Taking Guangxi as an example, cooperation with ASEAN is still mainly concentrated in labor-intensive and resource-intensive industries such as agricultural product cultivation and agricultural product processing. There is less cooperation in emerging industries such as the Internet and energy-saving and environmental protection industries, and innovative service industries. China's small and medium-sized enterprises are also mainly engaged in low-end product processing and assembly links, with short production chains, low added value of products, low technical content of products, and weak international competitiveness.

At the same time, China 's small and medium-sized enterprises export less ASEAN-branded products, and many foreign-produced enterprise product brands are not well-known in the ASEAN market. Most of the products exported by small-scale trade at the border are mixed products with low-end and unbranded products. Enterprise product brand is an enterprise's intangible wealth and a stepping stone to enter a market. However, due to backward equipment and processes, weak technological innovation capabilities, and lack of patented technology, it is difficult to form independent brands, which is not conducive to the sustainability development of SMEs. The lack of independent brands and irrational product structure have seriously weakened the market competitiveness of SMEs in developing foreign trade. This makes it difficult for SMEs to expand international markets and form stable export channels.

\subsection{Poor Foreign Trade Knowledge and Lagging of Talent Team}

Generally speaking, most SMEs 'operators or managers have a low level of education and lack of professional modern management knowledge. Managers rely on personal experience to manage enterprises. Generally speaking, the managers or managers of most small and medium-sized enterprises have a low level of education and lack professional modern management knowledge. Managers can rely on personal experience to manage enterprises in domestic, but in the face of complicated market environment and trade barriers abroad, it is not enough to rely on personal experience alone. In the process of cooperation between China and ASEAN countries, language barriers, lack of information in the international market and lack of foreign trade knowledge are common weaknesses of small and medium-sized enterprises in foreign trade. Especially in the context of the "Belt and Road" development, China 's small and medium-sized enterprises are even more deficient in small-language talents in ASEAN countries. There are obstacles to external exchanges when communicating and cooperating with enterprises in ASEAN countries. It is impossible to communicate market information and professional technical issues in a timely manner. When communicating and cooperating with enterprises in ASEAN countries, there are obstacles to external communication. Failure to communicate market information and technical issues in a timely manner. It has brought many difficulties to the construction of cooperative projects between SMEs and foreign countries. Moreover, due to their small scale, most SMEs do not have sufficient funds and strength to train and attract high-quality foreign trade talents. Most SMEs can only rely on consulting companies or outsourcing companies for indirect foreign trade operations.

\section{Policy recommendations for deepening cooperation among SMEs}

\subsection{Deepening Policy Communication and Regional Cooperation to Enhance Political Mutual Trust}

In order to better promote the smooth implementation of the "Belt and Road" initiative and strengthen cooperation between China and ASEAN enterprises, it is necessary to deepen policy communication and regional cooperation between China and ASEAN countries and strengthen political mutual 
trust between China and ASEAN countries. While strengthening policy communication and strategic unification, China should also strengthen its own strength and participate in international competition actively. At present, the loose internal structure of ASEAN makes the road of common development between China and ASEAN full of uncertainty, it is difficult for both sides to reach an agreement on the same issue. Therefore, it is particularly important to strengthen subregional cooperation. China should take the "Lancang-Mekong cooperation" as an opportunity to continuously strengthen its production capacity cooperation with Cambodia, Laos, Myanmar, Thailand and Vietnam, and strive for early interconnection. The successful cases of China-ASEAN cooperation have strengthened China's influence and international image in ASEAN countries.

At the same time, through continuous bilateral negotiations, China-ASEAN bilateral trade barriers will be gradually reduced, which will provide more fair treatment for Chinese SMEs' investment and operations in ASEAN countries, reduce investment risks for SMEs, and enable SMEs to better participate in international markets competition. Despite the differences in ideology between China and ASEAN countries, the pursuit of common development is interconnected. China should make ASEAN countries realize that China is actively maintaining and benefiting from the existing international order. 2020 is the 17th year that China and ASEAN have established a strategic partnership. Taking this as an opportunity, China should, based on the current and long-term perspective, promote the building of a closer China-ASEAN community of shared destiny and improve the level of mutual trust between the two sides.

\subsection{Establish an Investment Information Consulting Platform to Promote Cooperation and Exchanges Between SME Organizations and Associations}

The government should set up SME investment advisory offices and expand the provision of consulting services to systematically provide investment and market information for SMEs. Governments of all countries should establish information exchange platforms for foreign trade business conditions. In this regard, it is recommended that the government and relevant institutions provide specific information such as business information, market environment and policy details for SMEs. Set up Chinese investment consulting windows in ASEAN countries, assist Chinese manufacturers to remove investment obstacles and solve operational problems, and attract enterprises from ASEAN countries to invest in China or cooperate with Chinese enterprises.

The government should actively guide and promote cooperation and exchanges between industrial organizations and associations at all levels. At the government level, in addition to promoting the China-ASEAN bilateral economic cooperation conference, it can also coordinate and organize various departments and SMEs to organize trade missions and exhibitions to assist Chinese enterprises in seeking trade and technical cooperation opportunities in ASEAN countries and develop economic and trade cooperation relations. At the level of industry associations and non-governmental organizations, establish cooperation channels for domestic enterprise organizations or industry associations to share information and jointly serve SMEs. China Association of Small and Medium Enterprises can establish cooperative relations with industry associations in ASEAN countries to more effectively promote China-ASEAN information communication and economic cooperation.

\subsection{Carrying out the Construction of the Credit system of the Foreign Trade Industry and Improving the Laws and Regulations of the Financing Mechanism}

Integrity management and legal financing of small and medium-sized enterprises not only rely on the rational financing of funds and the improvement of business performance, but also rely on the credit awareness of senior managers. Therefore, the government should start the credit rating work of China's foreign trade enterprises to solve the long-standing problem of credit opacity in China's foreign trade enterprises. With the support of the government, it is necessary to carry out the construction of the credit system of the foreign trade industry, realize the transparency of credit information of foreign trade enterprises, effectively improve the credit awareness of SMEs, and make it easier for SMEs to finance international trade. It is necessary to incorporate SMEs' international trade financing into the credit management system, establish a specialized bank risk assessment department, conduct risk ratings on relevant international trade finance SMEs, verify risks or credit lines, and conduct operational control by front-line departments. The annual national credit rating activities of foreign trade enterprises are implemented, and the credit information of foreign trade enterprises is released in a timely, fast and accurate manner, so that the credit system of foreign trade enterprises can truly play its due role.

At the same time, China's legislative department should strengthen the improvement of policies and laws on international trade financing. Starting from the loopholes in existing laws and regulations, analyze the existing problems between international practices and current Chinese laws, provide a basis for scientific legislation, and formulate practical and feasible the operation plan is in line with international practices and practices, and further promotes the development of China's international trade financing.

\subsection{Improving Independent Innovation Capabilities and Improving Product Brand Structure}

Strengthening the capability of independent innovation is a necessary condition for the survival and development of enterprises. In the context of the "Belt and Road", China is vigorously promoting independent innovation, thereby driving the progress of foreign trade. Domestic SMEs can accelerate the technological innovation, transformation and upgrading of foreign trade enterprises by drawing on and learning from China-Africa trade experience and foreign advanced science and technology, and strengthen foreign 
exchanges and cooperation of SMEs in the Internet and energy conservation and environmental protection fields. Small and medium-sized enterprises should establish a sense of quality and competition, improve product quality and improve the after-sales service system, continuously improve their core competitiveness through the competition, expand their marketing network, strengthen the promotion of product services, and build their own product brands, so as to establish a good corporate image.

China and ASEAN cooperate to establish a multinational service outsourcing information platform to connect domestic contracting needs with ASEAN outsourcing needs, collect a list of domestic manufacturers that are willing to contract ASEAN countries 'business, and publish the scale, scope and business scope of ASEAN countries' outsourcing companies Related professional information such as professional licenses, and published successful cases of cooperation between Chinese enterprises and manufacturers in ASEAN countries, which stimulated the enthusiasm of domestic SME contract manufacturers. The government should assist in the selection of key and advantageous industries, develop common brands, and assist SMEs to develop common brands. Assisted by the overall support system of professional managers, information consulting platforms, low-interest loans, and media promotion, China's small and medium-sized enterprises are promoted to develop common brands in ASEAN countries, and overseas personnel of relevant institutions are used to help SMEs establish brand strategic alliances. The government can set up specialized agencies in ASEAN countries to assist SMEs in outsourcing or contracting $\mathrm{R} \& \mathrm{D}$ activities, so as to reduce the risks and difficulties of cooperation between SMEs and ASEAN enterprises.

\subsection{Focus on Talent Training and Introduction, Build a Foreign Trade Talent Team}

Enterprise managers should pay attention to the cultivation and introduction of talents, introduce professional personnel in small languages or related to business operations, and improve the ability of SMEs to expand international markets and technological innovation. At the same time, enterprises also need to regularly train foreign trade talents to improve the business level and working ability of employees; establish a reasonable reward mechanism, increase bonuses and welfare funds, and increase employee motivation. Enterprises can rely on the strength of the government to strengthen the training of professional and technical talents, to meet the needs of the country's "Belt and Road" construction, to catch up with the times, and the government can assist SMEs to introduce professional talents from abroad.

The government can organize a delegation to recruit overseas scientific and technological talents, establish a channel with ASEAN to recruit local talents, assist small and medium-sized enterprises to introduce talents from ASEAN countries, and especially strengthen the introduction of talents who are proficient in Chinese, Internet technology, energy conservation and environmental protection. China-ASEAN Talent Recruitment Fairs are regularly held to strengthen the development of overseas technology talents and China's SME supply and demand platform to provide SMEs with information on talent recruitment related activities and policies. To provide financial subsidies or low-interest loans to small and medium-sized enterprises facing limited resources, unable to reach the scale of research and development, and lacking research and development talents in the innovation research process, so as to improve the training and introduction of talents for SMEs and build a high-level and high-quality China-ASEAN Foreign trade talent team.

\section{Conclusion}

Affected by historical background and international factors, bilateral and multilateral relations between China and ASEAN countries still face problems such as political mutual trust deficits and imbalanced economic and trade development. The small scale of SMEs and their weak competitiveness in the international market have also hindered the further deepening of China-ASEAN SME cooperation. Our government should actively strengthen exchanges and interactions with ASEAN countries. We must deepen policy communication and regional cooperation with foreign countries to enhance mutual political trust. Internally, we need to develop a credit system for the foreign trade industry, improve laws and regulations on financing mechanisms, and actively provide support to small and medium-sized domestic and foreign enterprises. Enterprises establish investment information consulting platforms to promote cooperation and exchanges between SME organizations and as sociations. SMEs as participants in China-ASEAN economic cooperation must also seize the opportunities of the "Belt and Road" to improve their independent innovation capabilities and corporate image, in order to improve their international market competitiveness and actively participate in international market competition. All in all, although there are still some obstacles and challenges within the two sides and the international community, win-win cooperation and common development are still the general trend. Strengthening China-ASEAN economic cooperation is the consensus reached between China and the 10 ASEAN countries. In the future, as long as China and the ASEAN countries continue to work together, under the guidance of the "Belt and Road" initiative, a new picture of regional economic cooperation in Asia will be drawn up, making greater contributions to the upgrading of the global economy.

\section{References}

[1] Zhu Meilin, Wang Liqin. Construction, Evolution and Trend of China-ASEAN Relations from the Speech of Chinese Leaders at China-ASEAN Leadership Conference [J]. Fudan International Relations Review, 2018 (02): 340-354.

[2] Quan Yi, Gao Junxing. Investigation Report on the Status of China's Construction of Overseas Economic and Trade Cooperation Parks in ASEAN [J]. Southeast Asia Aspect, 2018 (06): 54-61 
[3] Zhao Diqiong. Research on Guangxi Small and Medium-Sized Enterprises Financing - Based on the Perspective of China-ASEAN Free Trade Area [J]. Academic Forum, 2012, 35 (01): $113-115+123$.

[4] Shen Tao, Xu Jingyi, Cao Mengzhen. Research on the Impact of Bilateral Exchange Rate Changes on China-ASEAN Capacity Cooperation from Multiple Perspectives [J]. Regional Finance Research, 2019 (09): 14-22.

[5] Nie Honglong. Research on the Competitiveness, Complementarity and Trade Potential of China-ASEAN Trade [J]. Reform and Opening up, 2019 (15): 32-37.

[6] Jin Dan. Research on Political and Diplomatic Strategies for Promoting China-ASEAN Cooperation under the Belt and Road Initiative [J]. Peace and Development, 2019 (02): 84-100 +136 .

[7] You Hongbing, Xu Mengyun, Wang Tiantian. Obstacles and Path Choices Facing the Deepening Development of China-ASEAN Financial Cooperation [J]. References in Economic Research, 2019 (05): 111-119.

[8] Cui Xiaojing, Xiong Xin. Improvement and Innovation of Tax Collection and Management Cooperation between China and the "Belt and Road" Countries [J / OL]. Academic Forum, 2019 (04): $61-71$ https://doi.org/10.16524/j.45-1002.2019.04.002.

[2019-10-30].

[9] Fu Yuanjia. Strategic Research on Guangxi's Comprehensive Participation in the 21st Century Maritime Silk Road [J]. Industrial Innovation Research, 2019 (05): 30-32 + 38 .

[10] Jiang Decui. Dilemma and Outlet of China-ASEAN Free Trade Area Investment Dispute Resolution Mechanism [J]. Hebei Law, 2020, 38 (05): 104-116.

[11] Yue Wen, Han Jian. Analysis of the influencing factors of enterprises using FTA exports [J]. Journal of Beijing Technology and Business University (Social Science Edition), 2020, 35 (02): 34-44.
[12] Cao Yunhua, Li Junsuo. ASEAN Economic Community and "21st Century Maritime Silk Road": Competition and Cooperation [J]. Guangdong Social Sciences, 2020 (02): 37-44.

[13] Shen Tao, Cao Mengzhen. A Study on the Influencing Factors of Dynamic Fluctuations in China's Export Trade with ASEAN_ — Based on the Data of Key Industries for Capacity Cooperation [J]. Guangxi Social Sciences, 2020 (01): 67-74.

[14] Sun Lin, Zhou Kexuan. The Impact of Regional Trade Policy Uncertainty on the Product Quality of Chinese Export Enterprises - Taking the China-ASEAN Free Trade Area as an Example [J]. International Trade Issues, 2020 (01): 127143.

[15] Gao Zhen, Zhao Shun, Ni Weihong, Zhong Guoshuang. Collaborative research on agricultural standards of countries along the "Belt and Road" _ Taking agricultural machinery trade between China and ASEAN countries as an example [J]. Science and Technology Management Research, 2020, 40 (01): 144-149.

[16] Peng Xueqing, Xia Fei, Chen Xiuqian. Is cultural identity a catalyst for China's export of ASEAN cultural products-an empirical test based on LSDV [J]. International Economic and Trade Exploration, 2019, 35 (12): 57-69.

[17] Wang Yonghui, Zhang Zheng. Preference for regional public products constructed by the China-ASEAN small multilateral cooperation mechanism [J]. Indian Ocean Economies Research, 2019 (06): 81-97 + 152 .

[18] Yun Qian. Analysis of the path of China-ASEAN financial cooperation under the "Belt and Road Initiative" [J]. Asia-Pacific Economics, 2019 (05): 32-40 + 150.

[19] Guo Yanjun. China-ASEAN "One Belt, One Road" Cooperation: Main Progress, Multiple Cognitions and Promoting Paths [J]. Contemporary World, 2019 (09): 61-66.

[20] Chen Xiulian. Research on the new structure of China-ASEAN economic and trade cooperation model under the "Belt and Road Initiative" [J]. International Trade, 2019 (07): 79-87 + 96. 